Acta Regionalia et Environmentalica 2

Nitra, Slovaca Universitas Agriculturae Nitriae, 2017, pp. 37-44

\title{
DEVELOPMENT OF INCOMES AND EXPENDITURES IN SLOVAK HOUSEHOLDS
}

\author{
Zuzana LAZÍKOVÁ \\ Slovak University of Agriculture in Nitra, Slovak Republic
}

The household income is one of the basic indicators of the human living standard in the countries or their regions. The indicator of income is very closely connected to the indicator of expenditures, which completes the view of the living standard of households. During the last two decades, there were some important events that have influenced the development of household incomes and expenditures in Slovakia, such as accession of the Slovak Republic into the EU, adoption of the common currency euro or economic crisis as well. In the last years, the net incomes as well as the net expenditures of the Slovak households have increased. According to the results, this trend will continue; however, the net expenditures will increase faster than the net incomes of households. Therefore, we can expect that the savings rate will decrease. On the other hand, the differences of net household income and expenditures among the regions of Slovakia were not eliminated. There is still a high difference of the net household income mainly between the Bratislava region and the Prešov region.

Keywords: households; incomes; expenditures; development; forecast

Household income is one of the basic indicators of human living standard because it influences the level and structure of household expenditures that enable to satisfy human needs (Rozborilová, 2002). In measuring household living standard, significant attention is paid to income of households but it is also important to know whether the income is able to cover expenditures for human living. The households income causes the changes in consumption and expenditure patterns (Stephens, 2001; Cutler, 2005; Farkhanda and Eatzaz, 2007) and the households make an adjustment to their income and expenditures to fulfil their needs during the economic crisis (Zurawicki and Braidot, 2004). Both indicators of income and expenditure enable the statistical analysis of living standard (Vojtková and Labudová, 2010).

Household income is a monetary sum which is paid to the individuals with a particular periodicity for their activities that are realised at labour market (wages) or capital market (rent, share on the profit, dividends, or other payments). Household income also includes allowances and social benefits (Michálek, 2010). Moreover, the retirement pension is a primary source of household income of the pensioners.

Household income is a general notion of its different categories. There are more categories of household income, such as total gross income, total disposable income (Ivančíková and Vlačuha, 2012), net income (Vojtková and Labudová, 2010) or disposable personal income (Statistical Office of the SR, 2016), that are considered as the key economic indicators of households. Total gross household income includes the income of all household members and the income components which are followed in a household, such as income from employment (gross income from employment and other income close to the gross income from employment), income received by the using of company car, gross monetary profit or loss from the business (including royalties), income from the property (income from the property rent, interests, dividends, profit of the capital investments), current social transfers (children allowances, housing allowance, unemployment compensation, retirement pensions, sickness benefits, or other similar benefits), education benefits, income of persons younger than 16 years and regular monetary transfers between the households (Ivančíková and Vlačuha, 2012). Total disposable household income is defined as the gross household income after deducting regular property taxes, regular paid transfers between the households (such as alimony) and income taxes and social insurance payments (Statistical Office of the SR, 2017; Ivančíková and Vlačuha, 2012). Net household income includes the net income from employment (net income after deducting income tax and payment for social and health insurance), income from business intended on the household needs, social incomes (pensions, sickness benefits, state social benefits, unemployment compensation), and other incomes (income from property, income from institutions and private persons, income from the sales of agricultural products, income from abroad and new loan) (Vojtková and Labudová, 2010). From the above mentioned definition of household income results, regardless of gross or net income, that there is no definition which is able to include all components of household income. Ivančíková and Vlačuha (2012) do not take into account new loan for households, Vojtková and Labudová (2010) neglect income of persons younger than 16 years. Moreover, there is one more notion of household income in the analysis of income inequality, called total equivalised disposable income of households. It 
is necessary for comparability of the various households. By the equivalence scale the equivalised size of household is computed. There is a problem that the universal equivalence scale is missing; there are many different equivalence scales that can be used. Tartal'ová and Želinský (2012) state that the choice of the equivalence scale depends on the technique conditions related to the amount of savings and needs of the particular household members regarding their age. The first equivalence scale is Oxford scale often called also the scale of OECD. Later, it was modified and this modified version is used by the EUROSTAT and the Statistical Office of the Slovak Republic as well. Moreover, there are two more scales such as the square root scale and the McClement scale used mainly in the Great Britain (Anyaegbu, 2010).

The second important category of household living of standard are expenditures, mainly consumption expenditures because they create about two thirds of total expenditures (Lisý et al., 2011). In general, the expenditures are the outflow of money from a household (Meyer and Sullivan, 2003). The highest household expenditures include expenditures for food, housing with energy and transport (Frendáková, 2010). It is the trend in all developed countries; however, there are great differences among the countries, e.g. the smallest expenditures for food and drinks are in the Great Britain (8.4\%), Luxemburg (9.4\%) and Ireland (9.5\%); the highest expenditure for food and drinks are in Romania (29.4\%), Lithuania (23.4\%) and Estonia (20.7\%) (Eurostat, 2016). The highest expenditures for housing are in Denmark (29.7\%) and Finland (28.2\%) and the smallest ones are in Malta (10.1\%) and Lithuania (15.8\%) (Eurostat, 2016). Transport expenditures range from $7 \%$ to $16 \%$ of total expenditures and the smallest ones are in Slovakia, Spain and Czechia; the highest ones are in Slovenia, Luxemburg and Bulgaria (Eurostat, 2016).

For evaluation of household expenditures, there are two categories of expenditures, the gross and net monetary expenditures. The gross monetary expenditures include consumption expenditures and other gross expenditures (i.e. income tax and obligatory social insurance and health payments). The net monetary expenditures include consumption expenditures and other net expenditures (i.e. other expenditures without income taxes and obligatory social insurance and health payments (Vojtková and Labudová, 2010).

\section{Material and methods}

The aim of the paper is to monitor the development of household income and expenditures in Slovakia (during the period of 2000 to 2015) and its regions (NUTS III) and to forecast their development in the next 4 years.

To follow the household income, the category total equivalised disposable income of household was used. The total equivalised disposable income of household is the total income of a household, after tax and other deductions, that is available for spending or saving, divided by the number of household members converted into equalised adults; household members are equalised by weighting each according to their age, using the equivalence scale. The modified OECD equivalence scale was used. The total net household income is divided by the number of equivalent adults using the modified OECD equivalence scale; this scale gives a weight to all members of the household: 1.0 to the first adult; 0.5 to the second and each subsequent person aged 14 and over, 0.3 to each child aged under 14 (Eurostat. Statistics Explained, 2014).

To follow the household expenditures, the net monetary expenditures were used which included consumption expenditures and other net expenditures without taxes and obligatory social insurance and health payments (Statistical Office of the SR, 2017).

We analysed the category of net household income and net household expenditures in Slovakia and its regions (NUTS III). However, the development trend of gross and net household income and expenditures is very similar in the period 2000-2015 in spite of the fact that the difference between gross and net categories of income and expenditures is slightly increasing (Statistical Office of SR, 2016).

The data was received from the Statistical Yearbooks and Regional Statistical Yearbooks published by the Statistical Office of the Slovak Republic in particular years.

To forecast the development trend of the household income and expenditure, the methods of time series analysis were used. By the special software (Statistical Analysis System SAS 9.3) we create the combined models described below. For the modelling of net household income development, the combined model included Winters additive model, model of linear trend with autoregressive errors and logarithmic Winters additive model. For the modelling of net household expenditure development, the combined model included Winters additive model, logarithmic Winters additive model and Winter multiplicative model. Winters method is a generalisation of exponential smoothing that includes not only trend component $\left(T_{t}\right)$ but also the seasonal components $\left(S_{t}\right)$.

Winters Multiplicative method is based on the multiplicative decomposition of time series defined as follows: $y_{t}=T_{t} S_{t} \varepsilon_{t}$, where $T_{t}$ is the trend component; $S_{t}$ is the seasonal component and $\varepsilon_{t}$ is the random error. The equation of Winters multiplicative exponential smoothing is defined as $Y_{t}=\left(\mu_{t}+\beta_{t} t\right) s_{p}(t)+\varepsilon_{t^{\prime}}$ where $\mu_{t}$ is the base signal called the permanent component; $\beta_{t}$ is a linear trend component; $s_{p}$ is a multiplicative seasonal factor and $\varepsilon_{t}$ is the random error component. Its forecast is defined as $\hat{Y}_{t}(k)=$ $\left(L_{t}+k T_{t}\right) S_{t-p+k^{\prime}}$ where $L_{t}$ is the estimate of the deseasonalized level; $T_{t}$ is the estimate of the trend; $S_{t}$ is the estimate of seasonal component and $k$ is $k$-step prediction a $p$ is number of seasons.

Winters additive decomposition of time series is defined as $y_{t}=T_{t}+S_{t}+\varepsilon_{t}$, where $T_{t}$ is the trend component; $S_{t}$ is the seasonal component and $\varepsilon_{t}$ is the random error. The equation of Winters additive exponential smoothing is defined as $Y_{t}=\mu_{t}+\beta_{t} t+s_{p}(t)+\varepsilon_{t}$, where $\mu_{t}$ is the base signal called the permanent component; $\beta_{t}$ is a linear trend component; $s_{p}$ is an additive seasonal factor and $\varepsilon_{t}$ is the random error component. Its forecast is defined as $\hat{Y}_{t}(k)=L_{t}+k T_{t}+S_{t-p+k}$ where $L_{t}$ is the estimate of the deseasonalized level; $T_{t}$ is the estimate of the trend, $S_{t}$ is the estimate of seasonal component and $k$ is $k$-step prediction a $p$ is number of seasons (Winters, 1960). 


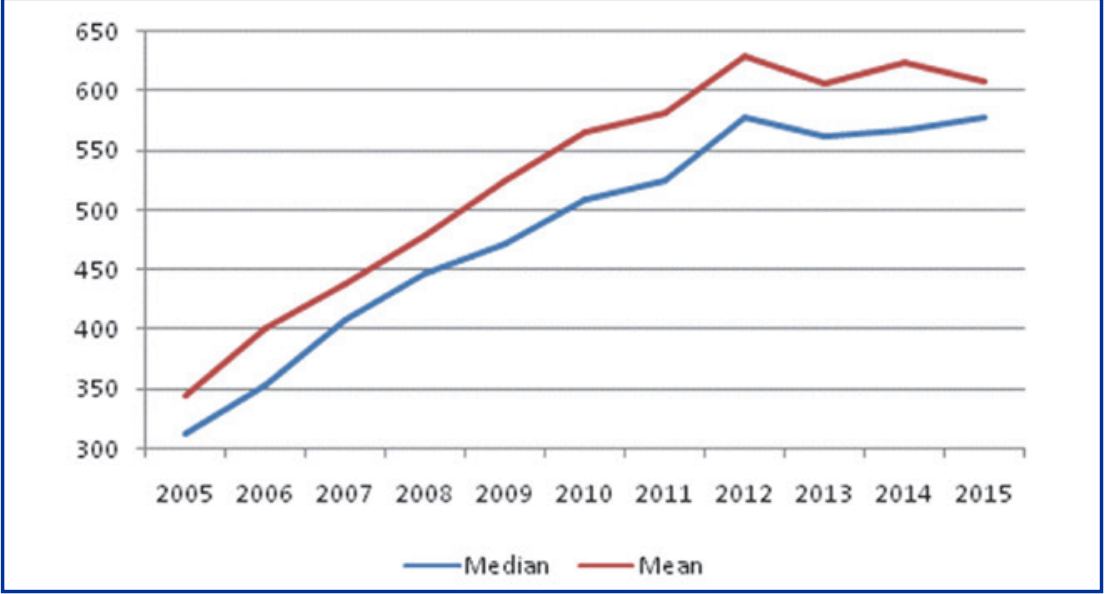

Figure 1 Mean and Median of the disposable equivalised household income in $€$ per month per one member of a household in Slovakia during 2005-2015 Source: Statistical Office of SR, 2016

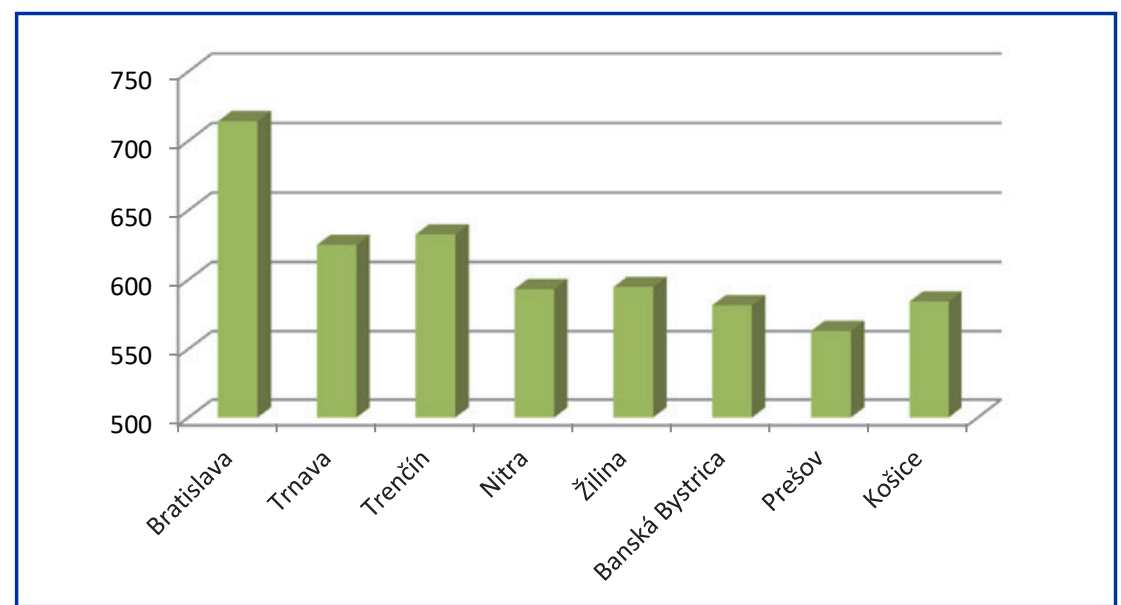

Figure 2 Mean and Median of the disposable equivalised household income in $€$ per month per one member of a household in Slovakia during 2005-2015 Source: Statistical Office of SR, 2016

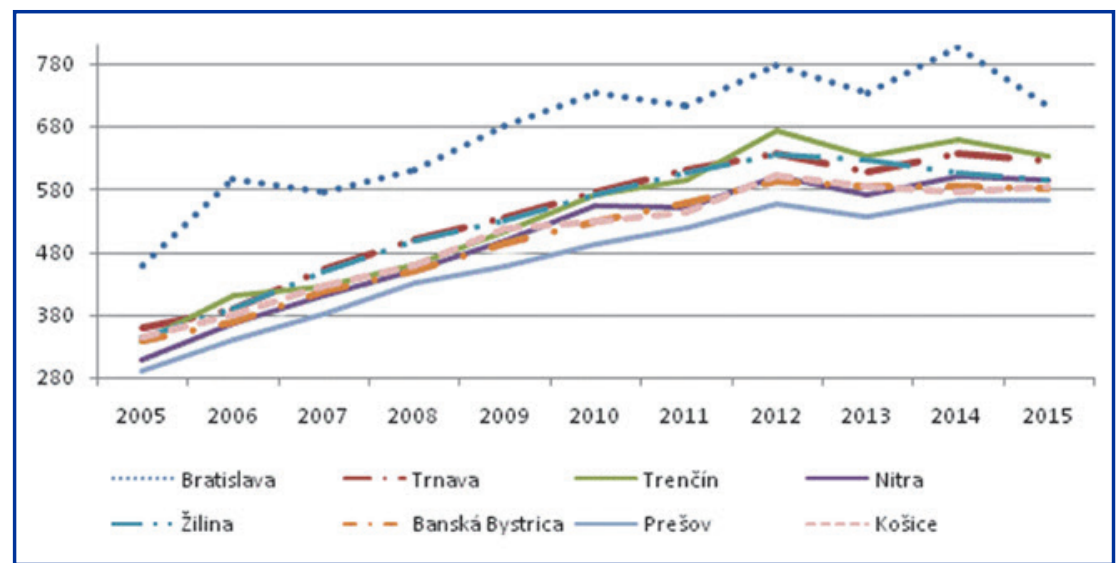

Figure 3 Development of the average disposable equivalised household income in $€$ per month per one member of a household in the Slovak regions during 2005-2015

Source: Statistical Office of SR, 2016

\section{Results and discussion}

Development of the household income

in Slovakia and its regions

During the last two decades, the Slovak Republic passed over a difficult development that is reflected also in the living standard of Slovak households, mainly in their incomes and expenditures. After the accession of Slovakia into the EU, we expected the increase of the living standard in Slovakia mainly by the increasing of the household income and expenditures. However, it was influenced by the adoption of the common currency euro and economic crisis as well. The dynamics of mean and median of equivalized household income in euro per person is presented in Figure 1.

The average disposable equivalised household income (red line) is higher than the median of disposable equivalised household income (blue line). It means that more than $50 \%$ of inhabitants have their disposable equivalised incomes smaller than the average income of a Slovak household.

The differentiation of income by the regional classification of inhabitants is considered as an important factor of household research (Vojtková and Labudová, 2010). The highest average disposable equivalised household income was recorded in the Bratislava region (714.23 $€$ per month in 2015). On the second position, there are the Trnava region and the Trenčín region. Their values of average disposable equivalised household income exceed $600 €$ per month in 2015. The rest of Slovak regions received the average disposable equivalised household income under $600 €$ per month in 2015. The lowest average disposable equivalised household income was recorded in the Prešov region (563.15€ per month in 2015) (Statistical Office of the SR, 2016). The differences of average disposable equivalised household income among the regions are documented in Figure 2.

However, the general trend of the average disposable equivalised household income is increasing in all Slovak regions. The trend is very similar among the regions, but there are great differences in the household income 
Table 1 Five best models for the forecasting of net income of households according to the criterion MAPE

\begin{tabular}{|l||c|c|c|c|}
\hline Model label & $\begin{array}{c}\text { Mean absolute percent } \\
\text { error }\end{array}$ & R-Square & $\begin{array}{c}\text { Akaike information } \\
\text { criterion }\end{array}$ & $\begin{array}{c}\text { Schwarz Bayesian } \\
\text { information criterion }\end{array}$ \\
\hline \hline $\begin{array}{l}\text { Winters method ... } \\
\text { additive }\end{array}$ & 2.06709 & 0.98584 & 252.83 & 259.01 \\
\hline $\begin{array}{l}\text { Linear trend with } \\
\text { autoregressive errors }\end{array}$ & 2.18698 & 0.98282 & 270.03 & 282.39 \\
\hline $\begin{array}{l}\text { Log Winters method ... } \\
\text { additive }\end{array}$ & 2.20639 & 0.98476 & 257.09 & 263.27 \\
\hline $\begin{array}{l}\text { Winters method ... } \\
\text { multiplicative }\end{array}$ & 2.20685 & 0.98420 & 259.18 & 265.36 \\
\hline $\begin{array}{l}\text { Log linear trend with } \\
\text { autoregressive errors }\end{array}$ & 2.28223 & 0.98203 & 272.65 & 285.01 \\
\hline
\end{tabular}

Source: self-calculation

Table 2 Forecast of net household income in $€$ per months and per one member of a household in 2016-2019

\begin{tabular}{|l||c|c|c|}
\hline Term/year & Forecasting value & Upper confidence interval (95\%) & Lower confidence interval (95\%) \\
\hline \hline Q1/2016 & 426.979 & 438.566 & 415.393 \\
\hline Q2/2016 & 440.276 & 454.553 & 426 \\
\hline Q3/2016 & 442.913 & 459.424 & 426.402 \\
\hline Q4/2016 & 457.778 & 476.614 & 438.941 \\
\hline Q1/2017 & 445.381 & 465.915 & 424.847 \\
\hline Q2/2017 & 458.493 & 481.146 & 435.84 \\
\hline Q3/2017 & 461.796 & 486.094 & 437.497 \\
\hline Q4/2017 & 476.629 & 503.081 & 450.177 \\
\hline Q1/2018 & 463.929 & 490.981 & 436.877 \\
\hline Q2/2018 & 477.158 & 506.254 & 448.062 \\
\hline Q3/2018 & 480.923 & 511.462 & 450.385 \\
\hline Q4/2018 & 495.974 & 528.74 & 463.209 \\
\hline Q1/2019 & 482.898 & 515.674 & 450.123 \\
\hline Q2/2019 & 496.399 & 531.309 & 461.488 \\
\hline Q3/2019 & 500.49 & 536.778 & 464.201 \\
\hline Q4/2019 & 515.892 & 554.581 & 477.202 \\
\hline
\end{tabular}

Source: self-calculation by SAS 9.3

among the regions of Slovakia. It is documented by the Figure 3.

During the observed period, the average disposable equivalised household income in the Bratislava region is higher than the highest average disposable equivalised household income in all other regions of Slovakia. The difference is $123.56 €$ per month on average. The opposite extreme is in the Prešov region, where the average disposable equivalised household income is the lowest of all other Slovak regions. During the observed period, it is by about $26.77 €$ on average lower than the lowest average disposable equivalised household income in other regions. In 2012 and 2013, the decreasing of the average disposable equivalised household income was recorded in all Slovak regions. In 2014 and 2015, the decreasing of the average disposable equivalised household income continued in most of the regions; however, the Prešov region and the Košice region recorded the increasing of the household income by about $9.12 €$ (Košice region) and $1.82 €$ (Prešov region).
By the time of the series analysis we tried to forecast the further development of household income. We used the data from 2000 to 2015 for SAS 9.3 which is able to create 582 models. We chose five best models according to the criterion Mean Absolute Percentage Error (MAPE).

From the list of the above mentioned models we chose the first three models where the conditions of white noise were fulfilled and the unit roots tests confirmed the stationarity of the residuals in the model. These three models were used to prepare the combined model to forecast the net household income in Slovakia (MAPE $=1.97915$ and R-Square $=0.987$ ). The results are documented in Figure 4.

In the future, we can expect that the net household income per month and per one member of a household will increase. However, the growth of household income will be slower than the growth of household income in 2006-2009. Moreover, the growth of household income will be faster than the growth of household income before the accession of Slovakia into the EU. In the period of the economic crisis 


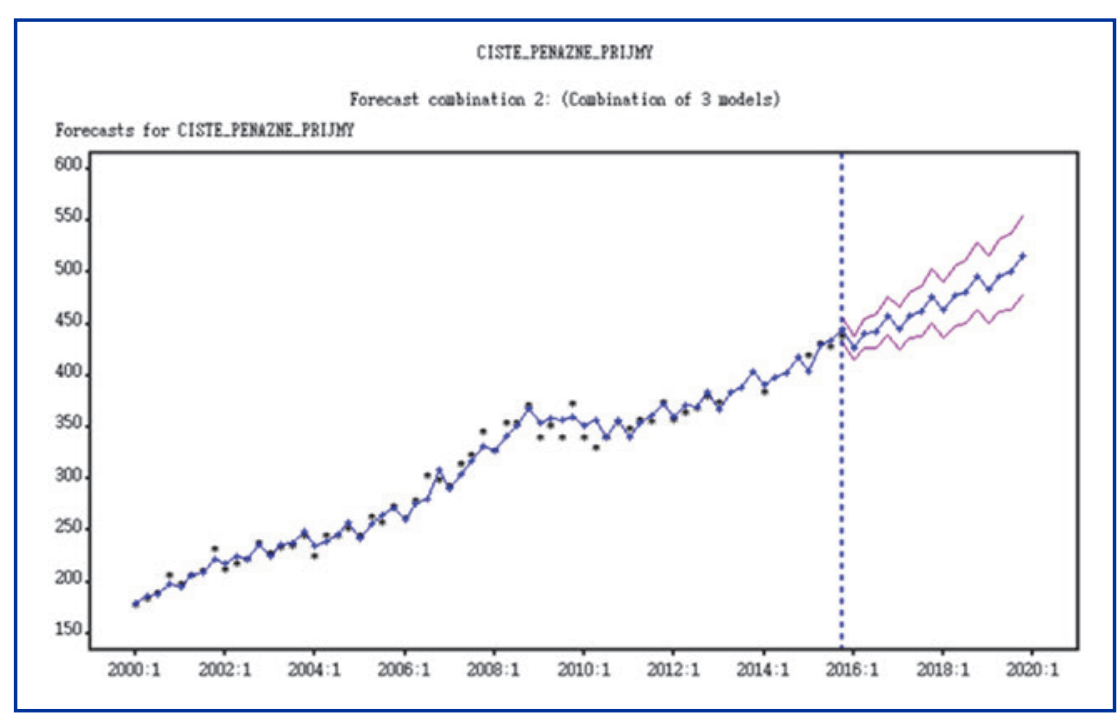

Figure 4 The recorded and the estimated development of net household income in $€$ per month per one member of a household in Slovakia 2000-2019 Source: self-calculation by SAS 9.3

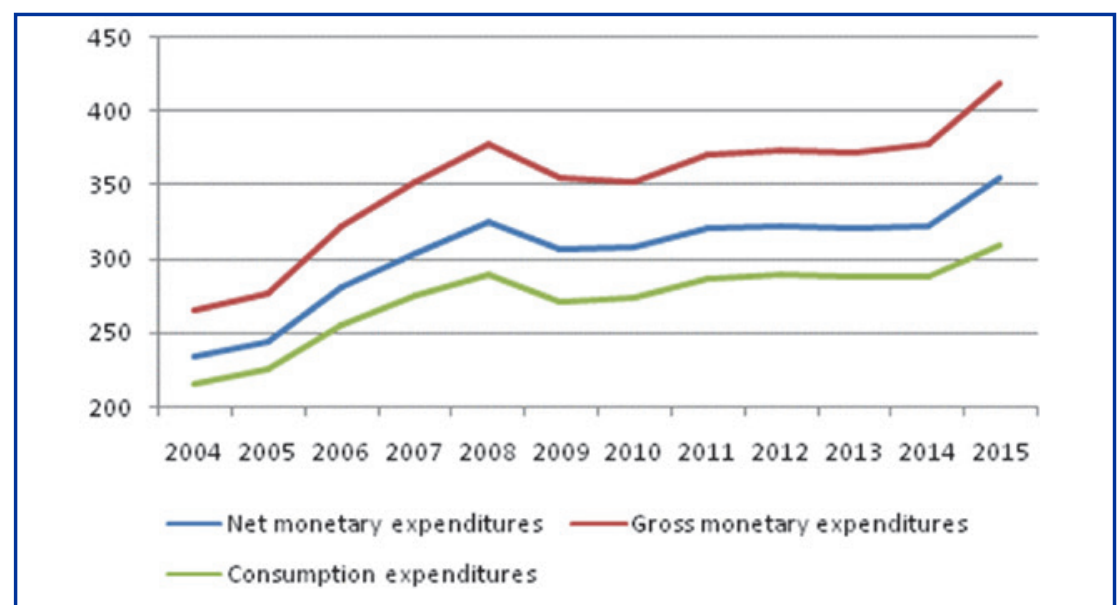

Figure 5 The development of the gross, net and consumption expenditures per month and per one member of a household in Slovakia in 2004-2015 Source: Statistical Office of SR, 2016

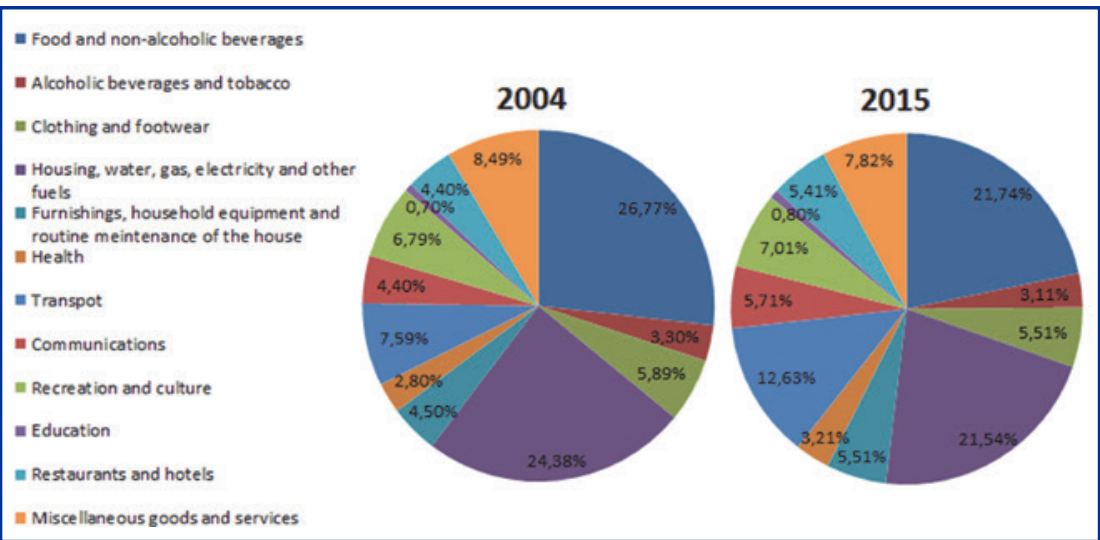

Figure 6 The structure of the consumption household expenditures in Slovakia in 2004-2015

Source: Statistical Office of SR, 2016
(2009-2011), there was recorded the decrease of the net household income. The forecast of net household income for the period 2016-2019 is recorded in the table 2.

\section{Development of the household expenditures in Slovakia and its regions}

Household expenditures include money that is used to satisfy all needs of household members. Statistical Office of the SR (2017) provides three categories of expenditures. Gross monetary expenditures include the consumption expenditures and other gross expenditures (i.e. including income taxes and obligatory insurance payments). Net monetary expenditures include the consumption expenditures and other net expenditures (i.e. expenditures without income taxes and obligatory insurance payments). Other expenditures are various payments such as property taxes, monetary gifts outside the households, instalment of credit, buying shares and short-term expenditures for small private business (Statistical Office of the SR, 2017). The third category is the consumption expenditures (i.e. expenditures for goods and services). The similar development of gross, net and consumption expenditures is documented in Figure 5.

During the observed period, the difference between the gross and net expenditures is increasing. The difference between the gross and net expenditures was $31 €$ in 2004 and $65 €$ in 2015. The tax payment and the payments for health and social insurance of households were increasing by 3.76 percentage point (p.p.) during the observed period of time. In 2015, it created $15 \%$ of gross expenditures of households. However, the difference between the net and consumption expenditures is also increasing (19 $€$ in 2004 and $45 €$ in 2015). It means that the share of consumption expenditures on the net expenditures is decreasing. In 2004, the household were able to use only $8 \%$ of net expenditures on other expenditures (excluding the consumption). In 2015, other expenditures created $12.5 \%$ of net expenditures of households. Other expenditures include mainly the credit payments, presents outside 
the households, investment in shares and bond papers, payments on voluntary insurance and others payments (Statistical Office of the SR, 2016).

In 2015, all three categories of expenditures received their maximum compared with the previous period.

The consumption expenditures are structured by the United Nation Classification of individual consumption by purpose (COICOP). The household expenditures are classified in the 12 fields by the purpose, which money is spent on (Statistical Office of the SR, 2017). The structure of the consumption expenditures in Slovakia according to the COICOP is documented in Figure 6.

The share of the consumption expenditures in the particular categories is changed between both years. The expenditures for food and non-alcoholic beverages were by about 5.1 p.p. in 2015 lower than they were in 2004. The decrease was recorded in the category of housing, water, gas, electricity and other fuels between both years by about 2.9 p.p. However, the increase of the consumption expenditures between 2004 and 2015 was recorded in the category of transport (5 p.p.) and communications (1.3 p.p.). The consumption expenditures in the category of education recorded the smallest change (only 0.1 p.p.).

The differences in the share of the consumption household expenditures were recorded also among the Slovak regions (Table 3 ).

The share of the consumption expenditures by the COICOP categories in the particular regions of Slovakia confirms the Engel's law - as income rises, the proportion of income spent on the basic needs such as food, housing or transport falls. Engel's law is confirmed mainly by the structure of the consumption expenditures in the Bratislava region. However, the Prešov region breaks the Engel's law. There was recorded the smallest average disposable equivalised household income, but the share of the consumption expenditures in the category of food and nonalcoholic beverages was smaller in the Prešov region than in the most other regions of Slovakia.

Table 3 The structure of the expenditures in percentages from the total net expenditures in 2015

\begin{tabular}{|l||c|c|c|c|c|c|c|c|}
\hline Region & BA & TT & TN & NR & ZA & BB & PO & KE \\
\hline Food and non-alcoholic beverages & 16.14 & 18.15 & 18.95 & 19.71 & 19.92 & 18.88 & 18.76 & 21.70 \\
\hline Alcoholic beverages and tobacco & 2.69 & 2.49 & 2.84 & 2.69 & 2.73 & 2.58 & 2.68 & 3.11 \\
\hline Clothing and footwear & 4.86 & 5.37 & 6.07 & 3.42 & 5.59 & 4.15 & 5.81 & 3.18 \\
\hline $\begin{array}{l}\text { Housing, water, gas, electricity } \\
\text { and other fuels }\end{array}$ & 18.97 & 18.02 & 16.76 & 19.81 & 17.10 & 20.32 & 18.39 & 21.46 \\
\hline $\begin{array}{l}\text { Furnishings, houselhold equipment } \\
\text { and routine meintenance of the house }\end{array}$ & 4.93 & 4.46 & 5.80 & 4.83 & 4.52 & 5.02 & 4.66 & 4.54 \\
\hline Healt & 2.73 & 2.33 & 3.03 & 2.97 & 3.01 & 2.51 & 3.43 & 2.66 \\
\hline Transpot & 10.09 & 11.20 & 11.24 & 10.25 & 12.55 & 11.64 & 11.94 & 9.71 \\
\hline Communications & 5.34 & 4.61 & 4.64 & 5.13 & 4.68 & 4.89 & 5.07 & 5.27 \\
\hline Recreation and culture & 7.08 & 5.28 & 6.81 & 6.91 & 6.32 & 6.37 & 4.76 & 5.63 \\
\hline Education & 0.56 & 0.63 & 0.74 & 0.66 & 0.97 & 0.63 & 0.55 & 0.89 \\
\hline Resaturants and hotels & 5.12 & 4.11 & 5.09 & 4.25 & 5.52 & 4.04 & 5.08 & 4.20 \\
\hline Miscellaneous goods and services & 6.71 & 6.52 & 7.06 & 6.77 & 6.95 & 6.88 & 6.66 & 7.25 \\
\hline Others net expenditures & 14.77 & 16.82 & 10.97 & 12.59 & 10.14 & 12.10 & 12.21 & 10.40 \\
\hline
\end{tabular}

Source: Statistical Office of SR, 2016

BA - Bratislava region; TT - Trnava region; TN - Trenčín region; NR - Nitra region; ZA - Žilina region, BB - Banská Bystrica region; $\mathrm{PO}$ - Prešov region; KE - Košice region

Table 4 Five best models for the forecasting of the net household expenditures according to the R-square

\begin{tabular}{|l|c||c|c|c|}
\hline Model label & R-Square & $\begin{array}{c}\text { Mean absolute percent } \\
\text { error }\end{array}$ & $\begin{array}{c}\text { Akaike information } \\
\text { criterion }\end{array}$ & $\begin{array}{c}\text { Schwarz Bayesian } \\
\text { information criterion }\end{array}$ \\
\hline $\begin{array}{l}\text { Winters method ... } \\
\text { additive }\end{array}$ & 0.95639 & 3.20805 & 280.75 & 286.88 \\
\hline $\begin{array}{l}\text { Log Winters method ... } \\
\text { additive }\end{array}$ & 0.95551 & 3.05922 & 281.88 & 288.01 \\
\hline $\begin{array}{l}\text { Winters method ... } \\
\text { multiplicative }\end{array}$ & 0.95519 & 3.16700 & 282.29 & 288.42 \\
\hline $\begin{array}{l}\text { Log Winters method ... } \\
\text { multiplicative }\end{array}$ & 0.95189 & 3.15231 & 286.35 & 292.48 \\
\hline $\begin{array}{l}\text { ARIMA (2, 1, 2) (1, 0, 1) } \\
\text { S NOIT }\end{array}$ & 0.94889 & 3.34085 & 287.77 & 299.92 \\
\hline
\end{tabular}

Source: self-calculation 


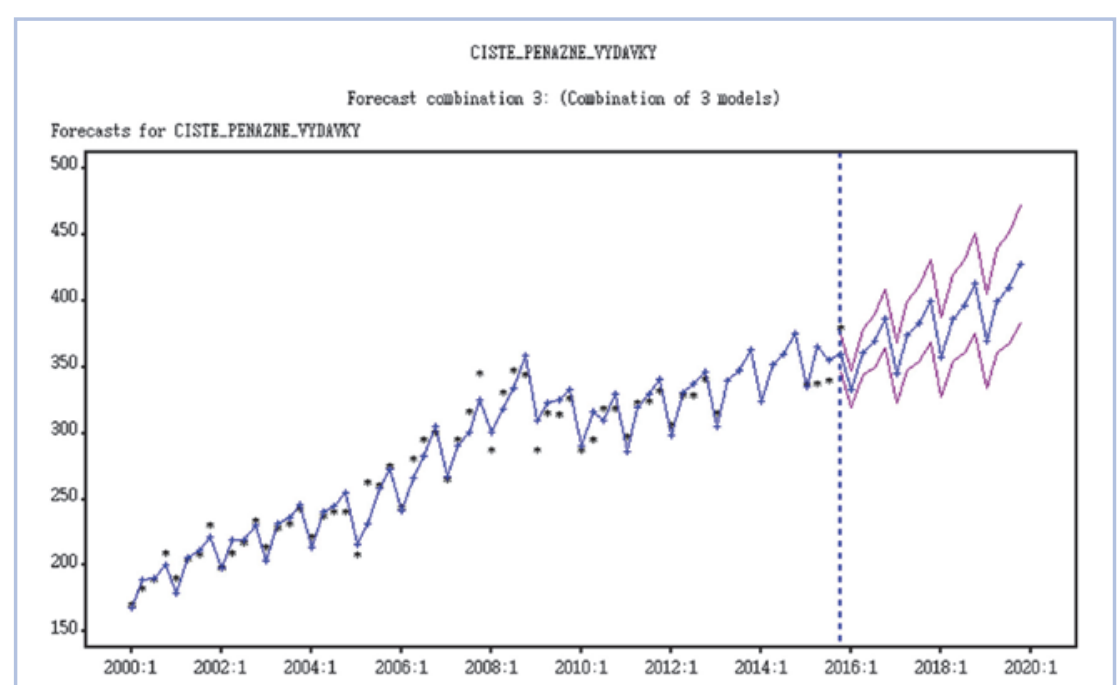

Figure 7 The recorded and estimated development of the net household expenditures in $€$ per month per one member of a household in Slovakia 2000-2019

Source: self-calculation by SAS 9.3

In 2015, the consumption expenditures for food and nonalcoholic beverages created $16.14 \%$ of the total net household expenditures in the Bratislava region, and $22 \%$ of the total net household expenditures in the Košice region. Housing, water, electricity, gas and other fuels were $16.76 \%$ of the total net household expenditures in the Trenčín region and more than $20 \%$ of the total net household expenditures in the Banská Bystrica region and the Košice region. However, the transport expenditures created $9.71 \%$ of the total net household expenditures in the Košice region, $10.09 \%$ of the total net household expenditures in the Bratislava region and $12.55 \%$ of the total net household expenditures in the Žilina region.

By the time of the series analysis we tried to forecast the further development of the net household expenditures. We used the data from 2000 to 2015 for SAS 9.3 which is able to create 582 models. We chose five best models according to the criterion R-square (table 4).

From the list of the above mentioned models we chose the first three models to create the combined model of forecasting of the net household expenditures. All models fulfilled the conditions of white noise and the unit roots tests confirmed the stationarity of residuals. The combined model has smaller value of MAPE $(3,1103)$ than the individual models and highest value of R-square $(0,957)$ than the individual model presented in the table 4 . The forecasting of the net household expenditures is documented in the figure 7 .

In the next years, we can expect that the net household expenditures per months and per one member of a household will be increasing; however their rate of growth will be similar to the values of the period after 2011 or the period before the accession of Slovakia into the EU. It means that their rate of growth will be slower than it was after the accession into the EU. During

Table 5 The forecast of the net household expenditures per months and per one member of a household in 2016-2019

\begin{tabular}{|l||c|c|c|}
\hline Term/year & Forecasting value & Upper confidence interval (95\%) & Lower confidence interval (95\%) \\
\hline \hline Q1/2016 & 333.26 & 346.966 & 319.555 \\
\hline Q2/2016 & 361.228 & 378.366 & 344.09 \\
\hline Q3/2016 & 369.919 & 389.736 & 350.103 \\
\hline Q4/2016 & 386.348 & 408.992 & 363.705 \\
\hline Q1/2017 & 345.246 & 368.09 & 322.402 \\
\hline Q2/2017 & 373.944 & 399.993 & 347.896 \\
\hline Q3/2017 & 382.842 & 411.075 & 354.608 \\
\hline Q4/2017 & 399.687 & 430.56 & 368.814 \\
\hline Q1/2018 & 357.441 & 387.266 & 327.615 \\
\hline Q2/2018 & 386.889 & 420.116 & 353.662 \\
\hline Q3/2018 & 395.998 & 431.28 & 360.715 \\
\hline Q4/2018 & 413.271 & 451.243 & 375.299 \\
\hline Q1/2019 & 369.852 & 405.849 & 333.856 \\
\hline Q2/2019 & 400.071 & 439.77 & 360.373 \\
\hline Q3/2019 & 409.398 & 451.137 & 367.659 \\
\hline Q4/2019 & 427.112 & 471.674 & 382.55 \\
\hline
\end{tabular}

Source: self-calculation by SAS 9.3 
the period of the economic crisis (2009-2011), the net household expenditures decreased. The level of the net household expenditures before the economic crisis was received again in 2013-2014. The forecasting of the net household expenditures is recorded in the table 5 .

According to the provided forecasting of the net household income and expenditures we can state that they will be increasing; however the net household expenditures will be increasing faster (app. by about $93 €$ ) than the net household income (app. by about $89 €$ ). Therefore, we can expect that the rate of the household savings which were increasing after the EU accession will be again decreasing.

\section{Conclusions}

Through the accession of Slovakia into the EU in 2004, our country entered the internal market of the EU. It caused that in Slovakia, the net household income and expenditures were increasing faster than during the period before the accession into the EU. Moreover, Slovakia prepared the conditions to fulfil the Maastricht convergence criteria and to adopt the common currency euro in 2009. The common currency caused that the household savings were increasing but their rates of growth were slowed by the economic crisis. The economic crisis caused a slight decrease in the net household income and expenditures as well. The new increasing of the net household income and expenditures were recorded in 2014-2015 and the results of the forecasting prove that we can expect their further increasing. However, the net household expenditures will be increasing faster than net household income and therefore, we can expect that the rate of household savings will be decreasing.

During the observed period, the differences of net household income and expenditures among the regions of Slovakia (NUTS III) were not eliminated. The net household income is similar among most of the regions; however, there is still a high difference of the net household income between the Bratislava region and the Prešov region. The share of the consumption expenditures by the COICOP categories in the particular regions of Slovakia confirms the Engel's law - as income rises, the proportion of income spent on the basic needs such as food, housing or transport falls. However, there is an exemption in the Prešov region; there was recorded the smallest average disposable equivalised household income, but the share of the consumption expenditures in the category of food and non-alcoholic beverages was one of the smallest compared to the other regions in Slovakia.

The above mentioned factors such as the accession into the EU, common currency and economic crisis have had an impact on the development of the net household income and expenditures in Slovakia, but they had not got any important influence on the reduction of regional disparities among the Slovak regions.

\section{References}

ANYAEGBU, G. 2010. Usingthe OECD equivalence scale in taxes and benefits analysis. In Economic\&Labour Market Review, vol. 4, no. 1, pp. 49-54. ISSN 1751-8326.
CUTLER, J. 2005. The relationship between consumption, income and wealth in Hong Kong. In Pacific Economic Review, vol. 10, no. 2, pp. 217-241. ISSN 1468-0106.

EUROSTAT. 2016. Eurostat Yerbook. Luxembourg: Eurostat, 2016. ISSN 2443-8219 [online]. [cit.2017-01-19]. Available at: <http://ec.europa.eu/eurostat/statistics-explained/index.php/ Europe_in_figures_Eurostat_yearbook>

EUROSTAT. 2014. Statistics Explained. online]. [cit. 2017-11-11]. Available at: <http://ec.europa.eu/eurostat/statistics-explained/ index.php/Glossary:Equivalised_disposable_income>

FARKHANDA, S. - EATZAZ, A. 2007. Understanding household consumption patterns in Pakistan. In Journal of Retailing and Consumer Services, vol. 14, no. 2, pp. 150-164. ISSN 0969-6989.

FRENDÁKOVÁ, A. 2010. Vývoj sklonu k úsporám slovenských domácností $v$ čase hospodárskej recesie. In National and regionaleconomics VIII. Košice : TUKE, pp. 287-295 ISBN 978-80553-0517-2 [online]. [cit. 2017-01-19]. Available at: http://www3. ekf.tuke.sk/konfera2010/zbornik/files/konfera2010_zbornik.pdf>

IVANČÍKOVÁ, L’. - VLAČUHA, R. 2012. Možnosti merania majetkovej chudoby na Slovensku. In Pauhofová, I. - Zelinský, T. 2012. Nerovnost' a chudoba v Európskej únii a na Slovensku. Košice : TU, pp. 39-48. ISBN 9788055312255.

LISÝ, J. et al. 2011. Ekonómia. Bratislava : Iuraedition, 631 p. ISBN 978-80-8078-406-5.

MEYER, D.B. - SULLIVAN, J.X. 2003. Measuring theWell-Being of the Poor Using Income and Consumption. In The Joint IRP/ ERS Conference on Income Volatility and Implications for Food Assistance, May 2-3, 2002 in Washington, DC. [online]. [cit. 201701-20]. Availbale at: <http://www.nber.org/papers/w9760>

MICHÁLEK, A. 2010. Sociálne nerovnosti a chudoba na Slovensku: regionálna analýza príjmov, miezd, chudoby. In Pauhofová, I. et al. 2010. Sociálny kapitál, l'udský kapitál a chudoba v regiónoch Slovenska. Košice : TUKE, pp. 13-21. ISBN 9788055305738.

ROZBORILOVÁ, D. 2002. Teória spotreby a úspor investícií a vládnych výdavkov. Bratislava : luraedition, 238 p. ISBN 80-89047-32-7.

STEPHENS Jr. M. 2001. The Long-Run Consumption Effects of Earnings Shocks. In The Review of Economics and Statistics, vol. 83, no. 1, pp. 28-36. ISSN 0034-6535.

ŠTATISTICKÝ ÚRAD SR. 2016. Štatistická ročenka Slovenskej republiky 2016. Bratislava: Štatistický úrad SR. [online]. [cit. 201701-19]. Available at: <http://www.statistics.sk>

ŠTATISTICKÝ ÚRAD SR. 2017. Metodické vysvetlivky. [online]. [cit. 2017-01-19]. Available at: http://www.statistics.sk/pls/elisw/objekt. sendName?name=metodika_S16>

TARTAL'OVÁ, A. - ŽELINSKÝ, T. 2012. Rozdelenie príjmov na Slovensku: Analýza citlivosti rozdelenia príjmov na volbu ekvivalentnej škály. In Pauhofová, I. - Zelinský, T. 2012. Nerovnost’ a chudoba v Európskej únii a na Slovensku. Košice :TU, pp. 99-106. ISBN 9788055312255.

VOJTKOVÁ, M. - LABUDOVÁ, V. 2010. Regionálna analýza výdavkov a príjmov domácností v Slovenskej republike. In Ekonomický časopis, vol. 58, no. 8, pp. 802-820. ISSN 0013-3035.

WINTERS, P.R. 1960. Forecasting Sales by Exponentially Weighted Moving Averages. In Management Science, vol. 6, no. 3, pp. 324- 342. ISSN 0025-1909.

ZURAWICKI, L. - BRAIDOT, N. 2005. Consumers during crisis: Responses from the middle class in Argentina. In Journal of Business Research, vol. 58, no. 8, pp. 1100-1109. ISSN 0148-2963. 